\title{
EMPOWERING EDUCATION SECTOR IN RURAL AREAS
}

\author{
Thomas Soseco
}

\author{
Universitas Negeri Malang, Indonesia
}

\begin{abstract}
More Indonesians moved from rural to urban areas in order to reach higher welfare. As a results, rural is seemed left behind urban, in term of infrastructure, welfare, and income distribution. Education in rural areas is one important thing to increase welfare and reduce inequalities. This research is aimed to search which education levels will best to reduce inequalities, and what policies are needed. The results are: (1). Elementary education could reduce income inequalities in rural and urban areas. While middle and high education will increase inequalities. (2). Government must builld better infrastuctures, also to spread out economic activities around all areas.
\end{abstract}

Keywords: rural areas, per capita income , inequality, education

\section{INTRODUCTION}

Urbanization is essential for development. As Simler and Dudwick (2010) stated, urban development is an integral part of economic development. Economic growth is invariably accompanied with a transition from a predominantly agararian economy to an economy dominated by the production of non-agricultural goods and services. While some of this transformation can take place in situ, as the rural non-farm economy grows and diversifies, the overriding pattern is one of increasing urbanization. Firms take advantage of agglomeration economies (the sharing of infrastructure, better matching of workers to jobs, and knowledge spillovers), which lead to what Arthur (1990) describes as "positive feedback"- a mutually reinforcing relationship between increases in productivity and the concentration of firms. similarly, people concentrate to take advantage of higher paying employment opportunities, better prices because of denser market, and improved amenities.

Annez and Buckley (2008) found that few countries have realized income levels of $\$ 10,000$ per capita before reaching about 60 percent urbanization; and simple bivariate regressions, while no indication of causality, suggest that urbanization is a very strong indicator of producivity growth over the long run, as seen in figure 1 .

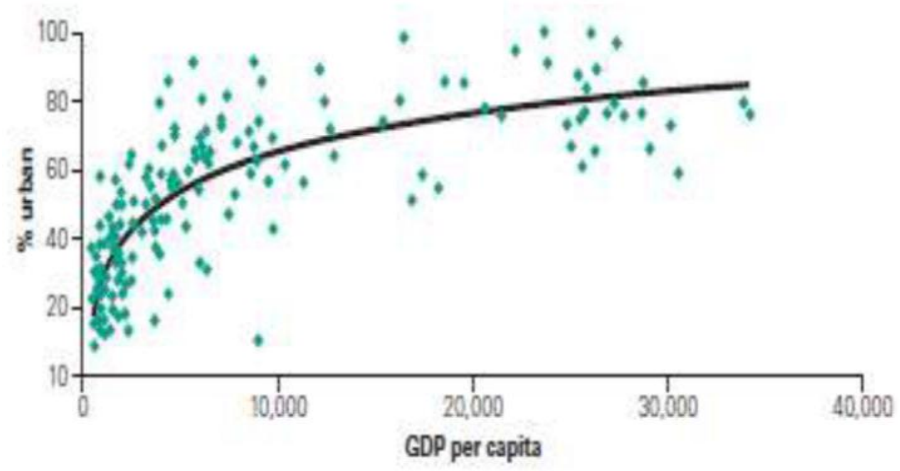

Figure 1. Urbanization and Per Capita GDP accross Countries, 2000. (Simler and Dudwick, 2010)

At early stages of development, economic growth and urbanization tend to increase spatial inequalities. Agglomeration drives to creation of leading areas. These areas indicated by superior economic growth, infrastructure, and income earned by their population. At the same time, there are lagged areas; commonly rural. These areas are easily indicate by lack of structural transformation and low level of standard of living.

From figure 1 we can conclude that urbanization is common phenomenon in countries low income

Corresponding Author: thomassoseco@gmail.com 
countries, especially for they who will gain S10,000 in GDP per capita. Higher the GDP per capita indicated by higher the percentage of population living in urban areas.

Indonesia exprienced a significant change in the number of population whi live in urban areas. From $12.4 \%$ in 1950 s to $46.7 \%$ in 2015 . Indonesia also has enormous rise in GDP per capita, from $\$ 600$ in 1950 s to $\$ 3,600$ in 2015 . As the better economy, Indonesia also faced worse rural and urban inequality, indicated by Gini ratio.

Table 1. Gini Ratio in Indonesia, 1964-2014

\begin{tabular}{cccc}
\hline Year & Urban & Rural & Urban+rural \\
\hline 1964 & 0.34 & 0.35 & 0.35 \\
\hline 1970 & 0.33 & 0.34 & 0.34 \\
\hline 1980 & 0.36 & 0.31 & 0.34 \\
\hline 1990 & 0.34 & 0.25 & 0.32 \\
\hline 1999 & 0.33 & 0.24 & 0.31 \\
\hline 2010 & 0.38 & 0.32 & 0.38 \\
\hline 2014 & 0.43 & 0.32 & 0.41 \\
\hline
\end{tabular}

Source: BPS (Many editions)

Table 1 showed us that there is an increase in Gini ratio in Indonesia in period of 1964-2014. Gini ratio in urban areas is relatively higher than in rural, indicating that income inequality in urban areas is higher than in rural.

Eventhough this condition is common exists in many developing countries, policymakers should not lay down and wait until the hypothesis in figure 1 comes true. Especially if the threshold is far in the future. Inequality is synonimed with social tension and even horizontal conflict. For Indonesia, big inequality potentially drives to state separation. Therefore, it is important to reducing gap between rural and urban areas.

Education is a portable asset (Simler and Dudwick, 2010). An expansion in its provision enables people to pursue a better quality of life in whatever geographical space they choose to make their home. Improvements in basic services in rural areas may, however, reduce excess migration to urban areas. Shilpi (2010) in Simler and Dudwick (2010) also stated that rural-urban migration choices are based not only potential income but also on prospective access to service. So, it development in education sector is important to prevent excessive migration and then can diminish large gap between urban and rural areas.

\section{LITERATURE REVIEW}

\section{Rural and Urban Areas}

Village in Indonesia in term of community and teritory was already exists since colonialism. As Hubeis (2011) stated that at least from Sir Thomas Stanford Raffles (1811-1816) recorded the existence of village especially in Jawa and Madura island. Both islands were the most intensive controlled and ruled under colonial government since 17 th century. In 1895 . approximately there were 30.000 villages in Jawa and Madura islands. with 21.237.031 population. with 409.216 population lived in capitals. It means that $19.2 \%$ population were categorized as urban.

Village is the smallest government structure in Indonesia. Based on Peraturan Pemerintah No. 72 Tahun 2005 (Government Act No. 72/2005). village is:

"Desa atau yang disebut dengan nama lain. selanjutnya disebut desa. adalah kesatuan masyarakat hukum yang memiliki batas-batas wilayah yang berwenang untuk mengatur dan mengurus kepentingan masyarakat setempat. berdasarkan asal-usul dan adat istiadat setempat yang diakui dan dihormati dalam sistem Pemerintahan Negara Kesatuan Republik Indonesia"

Village is one compact legal community that has spesific borders and has authority to rule and take care its own people. based on inheritance and tradition which respected by Indonesian government.

As an administrative area. a village must has certain prequisites. for example population. specific controllabe area. local officer. and governmental infrastucture. As a consequence. village can plays role as a residential. local government providers. social. and economic activities centres.

Undang-undang No. 22 Tahun 1999 (Indonesian Law No. 22/1999) stated that city is defined as an area that has non-agriculture main activity which serve as a centre for governmental services. social services. economic activities.

Sometimes. villages influenced by urban aspects. It means that villages no longer plays their original role. For instance. villages surrounding a city 
transforms themselves to residential places for commuters. leaving agriculture activities behind. Urban refers to a place that fulfills specific criteria that called urban. On the other hand. rural refers to an area that has specific criteria that called rural. The difference between urban and rural are:

1. Population density. Urban has higher population density comparing to rural.

2. Natural environment. Rural has more plantation. unpolluted air and water comparing to urban.

3. Employment sector. Because of limited space in urban. people work in nonagricultural sector (which requires large land). Urban people usually work in industry and services.

4. Social stratification. Industry and services that grow well in urban require employees with specific qualification. Thus. this leads to a wide range of specialization and salary paid.

5. Living pattern. Living pattern in urban is more heterogenous than in rural. This indicated from various ethnic. religion. and background of urban people.

6. Interaction pattern. Urban people usually maintain individualistic style. On the other hand. togeherness is vividly found in rural areas.

7. Solidarity. Conflicts that exists in rural areas are commonly solved with social norms or tradition. Conversely. conflicts in urban are solved with formal or legal solutions.

Relationship between rural and urban is shown in table 2 .

Table 2. Urban and Rural Linkages and Interdepence

\begin{tabular}{|lll|}
\hline \multicolumn{1}{|c|}{ Urban } & & \multicolumn{1}{c|}{ Rural } \\
\hline Agricultural & $\leftrightarrow$ & Agricultural production \\
trade/transport & & \\
centre & & \\
Agricultural support & $\leftrightarrow$ & $\begin{array}{l}\text { Agricultural } \\
\text { intensification }\end{array}$ \\
services & & * rural infrastructure \\
* production input & & $*$ production incentives \\
* repair services & & $*$ education and \\
production & & capacity \\
methods & & adopt/adapt \\
(innovation) & & innovation \\
Non-agricultural & $\leftrightarrow$ & Rural income and \\
consumer markets & & deman for non- \\
\hline
\end{tabular}

\begin{tabular}{|c|c|c|}
\hline & & $\begin{array}{l}\text { agricultural goods and } \\
\text { services }\end{array}$ \\
\hline $\begin{array}{l}* \text { processed } \\
\text { agricultural } \\
\text { products }\end{array}$ & & \\
\hline * private services & & \\
\hline $\begin{array}{l}* \text { public services } \\
\text { (health, } \\
\text { education, } \\
\text { administration) }\end{array}$ & & \\
\hline Agro-based industry & $\leftrightarrow$ & $\begin{array}{l}\text { Cash crop production } \\
\text { and agricultural } \\
\text { diversification }\end{array}$ \\
\hline $\begin{array}{l}\text { Non-agricultural } \\
\text { employment }\end{array}$ & $\leftrightarrow$ & All of the above \\
\hline
\end{tabular}

Source: Douglas (1998) in Daryanto and

Nuryartono (2011)

\section{Inequality}

Inequality means the difference between two group of people, or between two regions. Inequality in our society can be seen clearly, for example, there is one family who has luxiorous properties, while the others don't have. That condition can be quantified into several measurements. It benefit us to compare inequality condition from one period to other. Esmara (1975) stated there are several ways to measure inequality:

1. Pareto Coefficient

Pareto stated that there is a close relationship between certain income with number of people who obtain that income. This can be draw in this formula:

$$
N=\frac{K}{x^{\alpha}}
$$

where $\mathrm{x}$ is certain income obtained by families or persons, $\mathrm{N}$ is number of families or person who gain income $\mathrm{x}$ or more, $\mathrm{K}$ is a constanta, and $\alpha$ is Pareto coefficient.

2. Gini Coefficient

Gini stated that there is a relationship between aggregate income and number of families or persons. Gini coefficient can be derived from Pareto Coefficient or Lorenz Curve. 


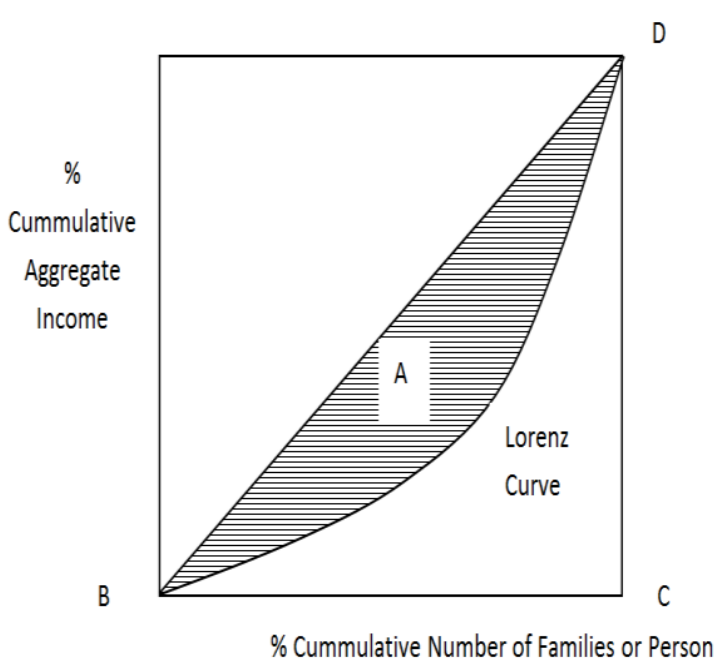

In Lorenz Curve, percentage of number of families or individual are arranged cummulatively (from lowest income to the highest) in horizontal axis. Then, vertical axis shows percentage cummulative aggregate income obtained. In perfect inequality, $10 \%$ of families or individual will receive $10 \%$ of aggregate income. By using other words, $\mathrm{x}$ percent of families wil receive $x$ percent of aggreagate income. This condition is reflected by diagonal line from bottom left to the upright.

If $x$ percent of families receive less than $x$ percent of aggregate income, the line will distract from diagonal line. An area between diagonal line and distractor line represents Gini Ratio.

Gini Ratio will valued from 0 (perfect equally) to 1 (perfect unequal). If Gini ratio less than 0.40 represents low inequality. If Gini Ratio valued between 0.40 to 0.49 represents medium inequality. Lastly, if Gini Ratio is more than 0.50 means severe inequality.

3. Gibrat Index

Gibrat said that income distribution among families or persons is not normally distributed, but has positive skewness. Therefore, income distribution is not normal or symmetric. Gibrat said that an increase in income is proportionally for each income classes. This caused by many factors, for example, age, workplace, and number of families.

4. Kuznets Index
Kuznets Index is an absolute gap between percentage of total income with total families or persons in all income class. Kuznets Index can be described with this formula:

$$
K=\sum_{i=1}^{k}\left|p_{i}-q_{i}\right|
$$

$\mathrm{p}_{\mathrm{i}}$ is percentage of income in class income $i, q_{i}$ is percentage of families or individuals in class $\mathrm{i}$, and $\mathrm{k}$ is number of classes.

5. Theil Index

Theil Index can described as follows:

$$
T=\sum_{i=1}^{b} q_{i} \cdot \log h \cdot q_{i}
$$

$h$ is number of families or individuals, $q_{i}$ is percentage of income received by families or persons. Theil Index will ranged from 0 to $\log \mathrm{h}$.

6. Oshima Index

Oshima Index can be described with this formula:

$$
O I=\frac{\sum_{i=1}^{10}\left|D_{i}-10\right|}{180}
$$

$\mathrm{D} i$ is percentage of total income in decille i. From that formula, total families or persons must be devided into ten similar groups (decille), based on the lowest income until the highest one. If all families or persons receive same income, thus each decille will gain $10 \%$ of aggregate income.

7. Economic Commission for Latin America (ECLA)

Several measurement developed by ECLA, i.e.:

a. Relative proportion from many income groups

ECLA divides population into four categories:

1. Low income population, which are $20 \%$ of population who obtain lowest aggregate income.

2. Moderate income population, which are $60 \%$ of population who gain moderate income. 
3. Upper moderate income population, which are $15 \%$ of population who receive upper moderate income.

4. High income population, which are $5 \%$ of population who receive highest income.

b. Income level and national average

ECLA compares income received to average income received by population or income class.

1. Population

ECLA compares percentage of population who receive certain income to national average income. Three categories of population are:

a. Under national average income.

b. Betwen national average income and doubled national average income.

c. More than double of national average income.

2. Income
a. Low income population.
b. Medium income population.
c. Upper medium income population.
d. High income population.

8. World Bank

World Bank divides income distribution into three categories. First, total income received by $40 \%$ of lowest income population. Second, total income received by $40 \%$ of moderate income population. Third, total income received by $20 \%$ of high income population. Inequality measures must be empasized on $40 \%$ of lowest income population. Thus, World Bank classifies 3 criteria of income distribution:

a. High level of inequality, means $40 \%$ of lowest income population received less than $12 \%$ of total income.

b. Moderate level of inequality, means $40 \%$ of lowest income population received $12 \%-17 \%$ of total income.

c. Low level of inequality, means $40 \%$ of lowest income population received more than $17 \%$ of total income.

\section{METHODOLOGY}

This research aimed to reveal relationship between development of education sector and income inequality between urban and rural areas in Indonesia. The developent of education sector is proxied by education attainment by age group (712 years, 13-15 years, and 16-18 years) both of rural and urban people. Income inequality is proxied by Gini ratio.

\section{RESEARCH QUESTIONS}

1. How did the development of education sector in rural areas can affect to rural and urban inequality?

2. What policies needed to reduce rural income inequality through education sector?

\section{FINDINGS}

Urban areas are commonly had higher welfare comparing to rural, in term of monetary and nonmonetary aspects. The welfare includes well-being, including mean consumption, poverty measures, children undernutrition, and school enrollment rates.

One indicator of welfare improvement is the change in consumption pattern. Based on economic theory, given the taste, the percentage of expenditure for food consumption will decrease as income increased. This pattern also occur in Indonesia, since its independence in 1945, the consumption pattern of the Indonesian population shifted gradually. The percentage of expenditure for food decreased from 69,5 percent of total income in 1980 to 49,96 percent in 2014. 


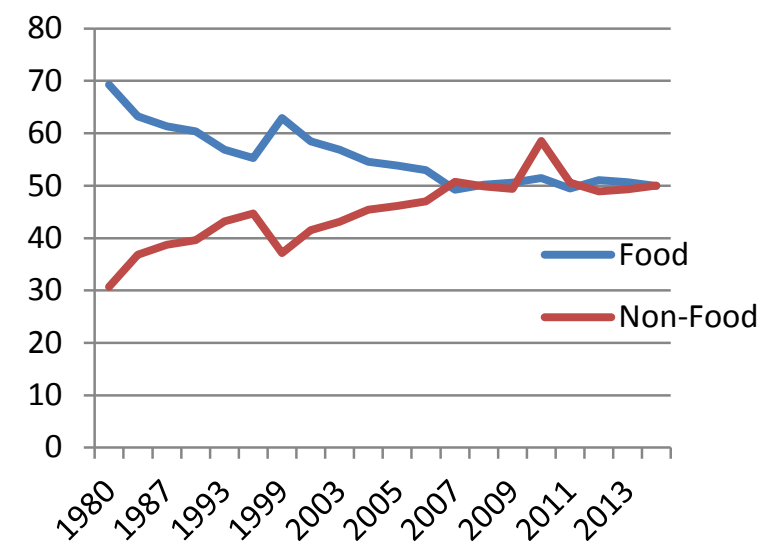

Figure 2. Monthly Expenditure for Food and NonFood (\%) (BPS, 2015)

Figure 2 shows that there is a gradual change in food and non-food consumption in Indonesia. in 1980 , Indonesians spent $69,30 \%$ of their income to buy food, while the rest, $30,70 \%$ are spent on nonfood. These number gradually changed until the period of crisis. In period of monetary crisis 1997/1998, Indonesians experienced significant increasement in food consumption, from $55,30 \%$ in 1996 to $62,90 \%$ in 1999. Then, in recent years, Indonesians spent their income on food and nonfood with almost in the same proportion. This figure showed that there is an increase in Indonesian economy. There is also a structural change in Indonesian economy, as seen in figure 3.

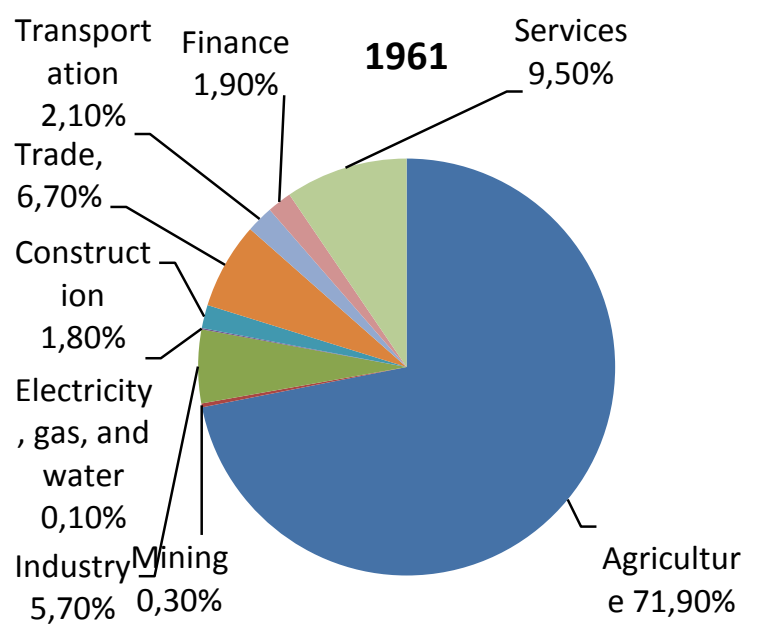

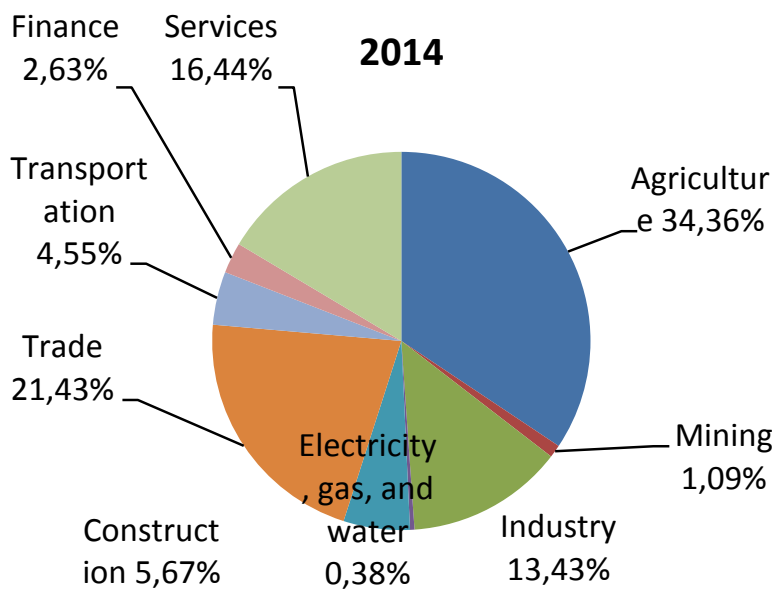

Figure 3. Workforce Distribution by Sectors, 1961 2014 (BPS, 2015)

Based on figure 3, there is a shift in percentage of workforce by sectors in Indonesia since 1960 to 2014. There was a decreasing percentage of workforce who work in agricultural sector, from $71,90 \%$ in 1961 to $34,36 \%$ in 2014.

In the same period, there was an increase in percentage of workforce who work in industry $(5,70 \%$ in 1961 to $13,43 \%$ in 2014$)$, trade $(6,70 \%$ to $21,43 \%)$, and services $(9,50 \%$ to $21,43 \%)$

Based on table 3, this research found that there is a positive relationship between school enrollment rate in urban to income inequality in urban areas, for all age group. Higher the school enrollment rate in urban people drives to higher inequality.

In contrary, there is negative relationship between school enrollment rate in rural areas to rural inequality. Higher the school enrollment rate among rural people can reduce gap among rural people. 
Table 3. Correlation Between Inequality and Education

\begin{tabular}{ccc}
\hline Age Group & Urban Inequality & Rural Inequality \\
\hline $7-12$ & 0,53832 & $-0,60359$ \\
\hline $13-15$ & 0,71270 & $-0,33497$ \\
\hline $16-18$ & 0,64956 & $-0,22451$ \\
\hline
\end{tabular}

This research developed four models which best represents the effect of education on income inequality, as described in table 4.

\section{Table 4. Four Models for Relationship between Income Inequality and Education}

\begin{tabular}{lll}
\hline No. & $\begin{array}{l}\text { Dependent } \\
\text { Variable }\end{array}$ & \multicolumn{1}{c}{ Independent Variables } \\
\hline 1. & $\begin{array}{l}\text { Rural } \\
\text { income } \\
\text { inequality }\end{array}$ & $\begin{array}{l}\text { Rural elementary education, } \\
\text { rural junior high school } \\
\text { education, rural senior high } \\
\text { school education }\end{array}$ \\
\hline 2. & $\begin{array}{l}\text { Urban } \\
\text { income } \\
\text { inequality }\end{array}$ & $\begin{array}{l}\text { Urban elementary education, } \\
\text { urban junior high school } \\
\text { education, urban senior high } \\
\text { school education }\end{array}$ \\
\hline 3. & $\begin{array}{l}\text { Rural } \\
\text { income } \\
\text { inequality }\end{array}$ & $\begin{array}{l}\text { Urban elementary education, } \\
\text { urban junior high school } \\
\text { education, urban senior high } \\
\text { school education }\end{array}$ \\
\hline 4. & Urban & $\begin{array}{l}\text { Rural elementary education, } \\
\text { rural junior high school } \\
\text { income } \\
\text { inequality } \\
\text { sedion, rural senior high }\end{array}$ \\
& & \begin{tabular}{l} 
school education \\
\hline
\end{tabular}
\end{tabular}

Using regression analysis, I found this results, as seen in table 5:

Table 5. Results

\begin{tabular}{|l|l|c|}
\hline No. & \multicolumn{1}{|c|}{ Results } & \multicolumn{1}{|c|}{$\begin{array}{c}\text { R- } \\
\text { squared }\end{array}$} \\
\hline 1. & $\begin{array}{l}\text { Rural inequality }=0.485724- \\
0.004392 \mathrm{R}_{1}+0.002648 \mathrm{R}_{2}+0.000356 \mathrm{R}_{3}\end{array}$ & 0.714064 \\
2. & $\begin{array}{l}\text { Urban inequality }=0.236721- \\
0.003211 \mathrm{U}_{1}+0.005363 \mathrm{U}_{2}-0.000371 \mathrm{U}_{3}\end{array}$ & 0.643260 \\
3. & $\begin{array}{l}\text { Rural inequality }=0.391808- \\
0.005592 \mathrm{U}_{1}+0.008441 \mathrm{U}_{2}-0.004656 \mathrm{U}_{3}\end{array}$ & 0.701280 \\
4. & $\begin{array}{l}\text { Urban inequality }=0.378877- \\
0.000574 \mathrm{R}_{1}-0.001660 \mathrm{R}_{2}+0.003906 \mathrm{R}_{3}\end{array}$ & 0.793750 \\
\hline
\end{tabular}

Note: $\mathrm{R}_{1}=$ Rural elementary education ( $7-12$ years), $\mathrm{R}_{2}=$ Rural junior high school education (13-15 years), $R_{3}=$ Rural senior high school education (16-18 years), $\mathrm{U}_{1}=$ Urban elementary education (7-12 years), $\mathrm{U}_{2}=$ Urban junior high school education (13-15 years), $\mathrm{U}_{3}=$ Urban senior high school education (16-18 years).
From table 5 we can conluded that elementary education (7-12 years) has negative effect on income inequality, in all four models. Then, junior high school education (13-15 years) has positive effect on income inequality in all models, except in model no. 4. Lastly, senior high school education (16-18 years) has positive effect on income inequality in model no. 1 and 4 and negative one in model no. 2 and 3.

In model no. 1, rural elementary education can reduce rural inequality. This condition mainly caused by the national programme (Gerakan Nasional Wajib Belajar) implemented since 1970s to force all of children to go to school. Government also build schools in around Indonesia and equipped them will updated infrastructure. Thus, families did not need to spend a lot of money to send their children to school. As a results, they can save money and then use it for other productive activities. The more 7-12 years old rural students who attain their study also will reduce income inequality in urban areas, as seen in model 4.

Next, the more 13-15 years old rural students who pass their junior high school will increase rural inequality and decrease urban inequality. At the same time, the more 13-15 years urban students who finish their junior high school will increase both urban and rural inequalities.

From model no. 1 and 4, rural senior high school education (16-18 years) will worsening income inequalities in rural and urban areas. Then, from model no. 2 and 3, urban senior high school education will reduce income inequalities in urban and rural areas.

So, which education is needed to reduce income inequalities? Elementary education (7-12 years) is urgently needed both in urban and rural areas because it can reduce inequalities. Higher the number of children who attain elementary education will provide better skill for them. Then, they will have higher productivity and higher income.

Next, junior high school education in urban and rural areas must be evaluated, because it can worsening income inequalites in urban and rural areas. Commonly, after graduated from junior high school, students will go to other areas to find better job. Their skills is not enough to compete with other workers. In contrary, senior high school in 
urban areas could reduce income inequalities both in rural and urban areas.

Senior high school education (16-18 years) in rural can increase both in rural and urban inequalities. In contrary, urban senior high school can reduce inequalities in both areas. Graduates of senior high school commonly will find non agricultural sectors. As seen in figure 4, in 2014, agricultural, construction, and mining sectors' workers are dominated by elementary school's graduates. Senior high schools graduates mostly work in electricity, gas and water, finance, trade, and transportation. Those sectors commonly found in urban areas. Thus, they will attract migration from rural, and worsening both urban and rural inequalities.

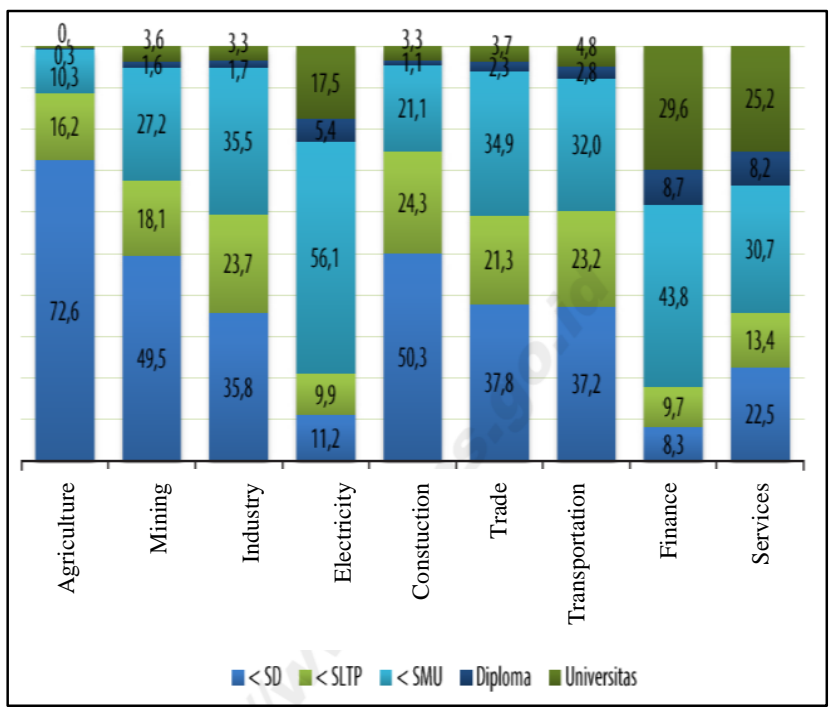

Note: SD = elementary school education, SLTP = junior high school educatio, SMU = senior high school education, Diploma $=$ three years higher education, Universitas $=$ four years higher education

Figure 4. Employment Proportion by Sectors and Education, 2013 (BPS, 2014)

\section{IMPLICATIONS}

Elementary education (7-12 years) in rural areas is the most important, because it can reduce both rural and urban income inequality. Unfortunately, most rural students stop their education after they finish their elementary education. There are several reasons: first, their parents do not allow them to go to school but force them to help in farming area. Parents seemed that it is sufficient for their children to have reading, writing, and mathematics only. Second, low interest for rural students to stay in their education. They prefer to work to obtain money than to study. For girls, they tend to get married in very young ages.

Junior high school (13-15 years) and senior high school (16-18 years) are also important, but should be directed to prevent workers' migration from rural to urban areas. This because students who graduated from middle or higher education tend to find better job with better salaries, for example work in factories, department stores, banks, or restaurants. All of them are commonly found in urban areas. Thus, this will attract people to migrate to urban, as found in Soseco (2016).

There are several actions must be taken:

1. It is important to make comprehensive understandings among rural people the importance of education.

2. It is urgent to spread out economic acivities to all around the nations. This aimed to make most economic activities are concentrated in certain areas only.

3. It needs better infrastructure to reach remotest areas, including build schools and equipped them with good learning facilities and supportive teachers.

\section{CONCLUSIONS}

1. Rural elementary education (7-12 years) can reduce income inequality, both in rural and urban areas. While middle (13-15 years) and higher education (16-18years) tend to increase the inequality.

2. It is important to build better infrastructure around all nation in order to spread out economic activities.

\section{REFERENCES}

Annez. P.C. and Buckley. R.M. 2008. Urbanization and Growth: Setting the Context. In Urbanization and Growth in P.C. Annez. et al. Eds. Urbanization and Growth. The Commission on Growth and Development (Washington DC: World Bank)

Arthur. B.W. 1990. Positive Feedback in the Economy. Scientific American. 262:92-99

BPS. 2014. Statistik Pendapatan 2013 
BPS. 2015. 70 Tahun Indonesia Merdeka

Daryanto, A and Nuryartono, N. 2011. Penguatan Ketahanan Masyarakat Desa (Community Resilience) dalam Pembangunan Sosial Ekonomi Desa. Menuju Desa 2030. Editors: Arif Satria. Ernan Rustiadi. and Agustina M. Purnomo. (Bogor: Crespent Press), pp. 63-79

Esmara, H. 1975. Perkiraan Pembagian Pendapatan di Indonesia (1925- 1973/ 74) (Padang: Lembaga Penelitian Ekonomi Regional Fakultas Ekonomi Universitas Andalas)

Hubeis. A.V.. et. al. 2011. Kesetaraan Gender dalam Pembangunan Perdesaan. Menuju Desa 2030. Editors: Arif Satria. Ernan Rustiadi. and Agustina M. Purnomo. (Bogor: Crespent Press), pp. 187-215
Simler, K. and Dudwick, N. 2011. Urbanization and Rural-Urban Welfare Inequalities. Draft for Discussion. Joint work program between PRMPR and FEUSE.

Soseco, T. 2015. Mendorong Sektor Pendidikan di Perdesaan. Jurnal Ekonomi dan Studi Pembangunan 7(2): 109-117

Sontosudarmo, A. 1990. Perkembangan Kualitas Sumberdaya Manusia Indonesia: Antara Harapan dan Kenyataan. Majalah Geografi Indonesia Th.46. No.6-9. September 1990-March 1992. Pp.53-59

www.revolusidesa.com accessed on 12 January 2016 